\section{Viden om vand}

Af Finn Christiansen, lektor i matematik, fysik og kemi på Risskov Amtsgymnasium.

Bogen "Viden om Vand" er beregnet til det naturvidenskabelige grundforløb i 1.g i det almene gymnasium. Ud over at dække de fag, som ligger i dette forløb, nemlig fysik og kemi, biologi og naturgeografi, er der også en videnskabshistorisk introduktion til vores nuværende forståelse af vand, og et afsluttende kapitel om vand som tema i religioner og mytologi. Det bliver dermed muligt at lade emnet indgå som et alment studieforberedelsesforløb.

Som nævnt indledes bogen med et videnskabshistorisk kapitel. Det viser tydeligt, at det har været vanskeligt videnskabeligt at få styr på det lille vandmolekyle. Det er således den fysisk kemiske side af vand, der fortælles om, mens den biologiske og geografiske side af sagen ikke belyses i dette kapitel.

\section{Vands fysiske og kemiske egenskaber} Derefter følger et kapitel om vands fysiske og kemiske egenskaber. Kapitlet kommer rundt om alle de væsentlige sider af emnet, men det kan på ingen måde stå alene, da de begreber, der berøres, ikke bliver forståelige ved så kort en omtale som hér.

Fx nævnes begreberne mol og molarmasse på ganske få linier. Det samme er tilfældet med specifik varmekapacitet og specifik fordampningsvarme. Det er erfaringsmæssigt vanskelige begreber for en 1.g'er. Begreber, der kræver opgaver og øvelser, før eleverne kan tilegne sig disse.

Det er således nødvendigt at have opgaver og øvelser fra andre kilder som supplement til bogen på dette felt. Det er dog på ingen måde vanskeligt at fremskaffe, men ofte er sådanne ting indbygget i de lærebøger, vi normalt anvender i 1.g.

\section{Vand i planter og i mennesker}

De to næste kapitler, som ligger inden for biologien nemlig, "Vand i planter" og "Vand i mennesket", er derimod mere velegnede til den mere fortællende og formelløse præsentationsform, som bogen anvender hele vejen igennem. løb samt vandløbssystemer.
I kapitlet "Vand i planter" omtales bl.a. det forunderlige $i$, at vand kan trækkes op til $100 \mathrm{~m}$ op i de høje træer, selvom det rent fysisk ville kræve et tryk på 10 atmosfære.

I kapitlet om "Vand i mennesket" er bl.a. nyrernes funktion forklaret, og selvom bogen ikke er så omfattende illustreret, som det ellers er blevet kutyme at gøre, er de medfølgende tegninger tydelige i deres billedsprog.

\section{Naturgeografisk indgangsvinkel}

De næste fem kapitler ligger inden for naturgeografien, og de kommer derved til at fylde omkring halvdelen af bogen. De synes for en person uden for faget at være ligeså lette at følge som de to biologikapitler, idet der også her bruges den fortællende form med gode illustrationer.

De første af de fem kapitler drejer sig om vand på Jorden. Det vil sige vandets kreds-

Det næste kapitel drejer sig om vand i fast form på Jorden. Nok ikke så almindeligt et emne i den almindelige undervisning?

Vi får en hel del at vide om gletschere

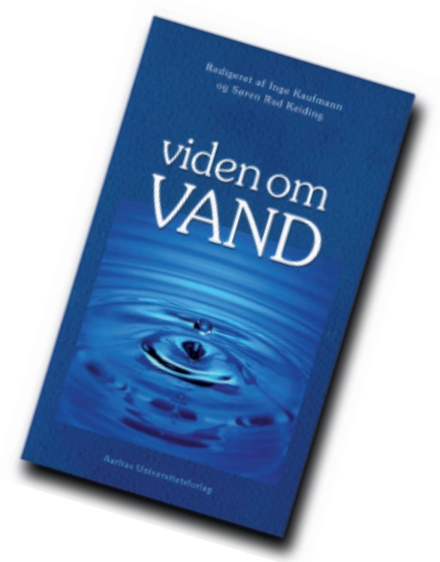

og et fænomen, som jeg ikke havde hørt om før: gletschergalop, som består i, at gletschere med omkring 100 års mellemrum kan begynde at bevæge sig op til 2 meter fremad i timen i en periode på ca. 3 år.

Det tredje kapitel i naturgeografien hedder: "Oceaner af vand", og med sin letgennemskuelige dobbelttydighed fortælles de foruroligende fakta om Golstrømmens mekanisme og mulige svækkelse på grund af den globale opvarmning. Denne opvarmning vil således få den katastrofale konsekvens for Skandinavien, at det bliver væsentligt koldere her.

Kapitlet giver også oplysninger om dannelsen af orkaner, som jo har fået en uhyggelig aktualitet på det seneste. Det er nemlig havets højere temperatur, som er årsagen til orkanernes dannelse.

Kapitlet slutter med emner som nærmest hører under biologien, idet havets evne til at optage carbondioxid hænger sammen med eksistensen af planteplankton og kalkflagellater.

Endelig afsluttes vand i forbindelse med 
vores klode med et kapitel om vand i atmosfæren, hvor vejrsystemer og skydannelse er hovedemnerne.

\section{Vand i rummet}

Bogens kapitel 9 om vand i rummet er også mest naturgeografisk, selvom forstavelsen geo- ikke er velanbragt. Her omtales eksistensen af vand på planeterne herunder naturligvis også vores Jord, men også Mars, hvor man efterhånden har så mange målinger, der ikke kan forklares på anden måde end, at der må være vand i undergrunden. Altså ikke bare, at der har været vand, som aflejringer fundet af Opportunity tyder på.

Da der er oxygen og hydrogen i rummet, er dannelsen af vand jo lige til. Det kan optages i mineralerne og frigøres derfra, efter planeten er dannet. Men meteorer kan naturligvis også være ankommet med det meste af vandet. Det er endnu ikke ganske afklaret.

Da vand er en helt afgørende forudsætning for liv af den slags, vi kender, er liv på andre planeter og måske en primitiv slags på Mars en oplagt mulighed.

\section{Fortallende stil}

Som nævnt er det den fortællende stil, som bogen anlægger - så vidt jeg kan vurdere, velegnet til formidling af naturgeografien, og den illustration, der følger, gør efter mit skøn bogen udmærket egnet til naturgeografi på det naturvidenskabelige grundforløb. At der så er meget mere, end tiden tillader,

\section{Kort nyt}

Hvorfor kan man skøjte?

Evnen til at skøjte på is forklares ofte med, at det høje tryk under den smalle skarpe klinge sænker isens smeltepunkt, og der derved opstår en tynd vandfilm mellem den faste is og klingens metal. Vandfilmen har lav viskositet og bevirker, at skøjteløberen bevæger sig næsten friktionsløst frem over isen. Argumentet daterer tilbage til John Joly, som i 1886 med baggrund i James og William Thomsons (senere Lord Kelvin) studier af tryksænkning af is' smeltepunkt beregnede, at en skøjteløber med et tryk på 466 atmosfære sænker smeltepunktet med $3,5^{\circ} \mathrm{C}$. Joly forklarede dog ikke, hvorfor det er muligt at skøjte ned til ca. $-30^{\circ} \mathrm{C}$, og netop denne uoverensstemmelse mere end antyder, at også andre forhold gør sig gældende.

F. P. Bowden og T. P. Hughes foreslog derfor i 1939, at isen smeltes af friktionen mellem skøjte og is. Bowden og Hughes verificerede teorien eksperimentelt og fandt, at trykinduceret smeltepunktssænkning kun spiller en rolle lige under smeltepunktet. Men selvom både tryk og friktionsmeltning at komme ind på, kan vel ikke siges at være en fejl.

\section{Religioner og mytologi}

Bogen afsluttes med et kapitel om vand som tema i religioner og mytologi, og heri fremhæves, at vand er et velegnet billede på det nødvendige, og på det der kommer til menneskene. Og det er ikke kun i Biblens Gamle Testamente, at det spiller en stor rolle, men også andre religioner tillægger vandet en både konkret og symbolsk betydning.

Vand er en nødvendig forudsætning for livets opretholdelse, og de gamle havde en intuitiv fornemmelse for, at vandet var til stede, før livet opstod. På den anden side kunne vandet også være årsag til en katastrofe, hvis det kom i for store mængder. Vandet kommer således til at ligge nær selve begrebet om det guddommelige, idet det ligger uden for mennesket, at det kan bringe velsignelse såvel som ødelæggelse.

Man kan roligt sige, at den naturvidenskabelige gennemgang, som bogen præsenterer, underbygger de mytiske forestillinger, som tidlige kulturer havde om stoffet vand.

Bogen er redigeret af Inge Kaufmann og Søren Rud Keiding. (Kapitlerne er skrevet af forskellige forfattere). 198,40 kr. excl. moms. Ved køb af 10 stk. eller mere er prisen $140 \mathrm{kr}$. excl. Moms. 176 sider haeftet og illustreret i farver. Aarhus Universitetsforlag 2005. ISBN: 8779342132. Til emnet er knyttet en hjemmeside: $w$ ww.vand.au.dk . bidrager til isens glathed, forklarer de dog ikke, hvorfor is også er glat, når man står stille på isen. Ej heller kan de to effekter forklare, at man kan skøjte ved $-30{ }^{\circ} \mathrm{C}$.

Forklaringen skal søges i, at der selv på is ved $-30{ }^{\circ} \mathrm{C}$ ligger et meget tyndt lag vand oven på isen. Faraday havde postuleret eksistensen af dette lag allerede i 1850, men først 100 år senere foreslog C. Gurney, at et sådant smeltelag kunne forklare, hvorfor is er så glat. Talrige eksperimentelle studier har senere påvist eksistensen af smeltelaget. Senest har målinger med Atomic Force Mikroskopi (AFM) vist, at vandlagets tykkelse varierer fra $12 \mathrm{~nm}$ ved $-24{ }^{\circ} \mathrm{C}$ til $70 \mathrm{~nm}$ ved $-0.7^{\circ} \mathrm{C}$, samt at isen begynder denne forsmeltning ved $-33^{\circ} \mathrm{C}$.

Computersimuleringer viser, at det reducerede antal bindinger til nabomolekyler på isens overflade får molekylerne til at vibrere med større amplitude end inde $i$ isen. Overfladesmeltningen tilskrives vekselvirkningen mellem netop disse molekyler og molekyler dybere $\mathrm{i}$ isen.

R. Rosenberg. Physics Today, 50, Vol 58 (2005) og referencer deri/JT 